\begin{tabular}{|c|c|c|}
\hline A & $\begin{array}{c}\text { Jurnal Bidan Cerdas } \\
\text { e-ISSN: 2654-9352 dan p-ISSN: 2715-9965 } \\
\text { Volume 3 Nomor 4, 2021, Halaman 146-158 } \\
\text { DOI: 10.33860/jbc.v3i4.580 } \\
\text { Website: http://jurnal.poltekkespalu.ac.id/index.php/JBC } \\
\text { Penerbit: Poltekkes Kemenkes Palu }\end{array}$ & \\
\hline
\end{tabular}

\title{
Determinan Fertilitas Remaja di Provinsi Nusa Tenggara Timur
}

\author{
Reski Ihsan Humang $\mathbb{1}^{1}$, Bs. Titi Haerana $₫ \mathbb{D}^{2}$, Yuniar Dwi Yanti®1 \\ ${ }^{1}$ Fakultas Kesehatan, Universitas Mega Buana, Palopo, Indonesia \\ ${ }^{2}$ Fakultas Kedokteran dan IImu Kesehatan, Universitas Islam Negeri Alauddin, Makassar, Indonesia \\ open \\ ¿Email: bs.titihaerana@gmail.com
}

access

\section{ARTICLE INFO}

Article History:

Received: 2021-09-27

Accepted: 2021-11-15

Published: 2021-11-30

Kata Kunci:

Fertlitas;

remaja;

determinan.

\section{Keywords:}

Fertility;

adolescent;

determinants.

\begin{abstract}
ABSTRAK
Pendahuluan: Fertilitas remaja menyebabkan berbagai konsekuensi negatif baik dampak kesehatan, sosial dan ekonomi. Tujuan: Mempelajari determinan fertilitas remaja di Provinsi di Nusa Tenggara Timur. Metode: Penelitian ini menggunakan data survei pada SDKI Tahun 2017. Sampel adalah remaja usia 15-19 tahun yang tercatat sebagai sampel terpilih di Provinsi Nusa Tenggara Timur (NTT) sebanyak 401 remaja. Analisis menggunakan regresi logistik berganda dengan model faktor prediktif. Hasil: Nilai aOR terbesar yakni status marital sebesar 17.25 (95\% Cl 6.60-45.04). Pendidikan hanya tamat SD aOR $4.94(95 \% \mathrm{Cl} 1.08-22.45)$. Tidak pernah mengakses internet aOR $3.37(95 \% \mathrm{Cl} 0.85-13.37)$. Setiap peningkatan 1 tahun usia remaja terjadi peningkatan odds sebesar $3.32(95 \% \mathrm{Cl} 1.71-6.46)$ kali. Tidak bekerja aOR $3.00(95 \% \mathrm{Cl} 0.71-12.66)$. Tinggal di daerah perdesaan aOR $2.55(95 \% \mathrm{Cl} 0.53-12.13)$. Pengetahuan metode $\mathrm{KB}$ yang rendah memiliki aOR 0.26 (0.05-1.22). Kesimpulan: Determinan fertilitas remaja di Provinsi NTT yakni usia, pendidikan, pekerjaan, status marital, tempat tinggal, penggunaan internet dan pengetahuan metode KB.
\end{abstract}

\section{ABSTRACT}

Introduction: Adolescent fertility caused various negative consequences starting from the occurrence of adolescent fertility include health, social and economic impacts. Purpose: to study the determinants of adolescent fertility in the Province of East Nusa Tenggara. Methods: This study uses secondary survey data in the 2017 IDHS. The sample was adolescents aged 15-19 years who were recorded as selected samples in East Nusa Tenggara Province as many as 401 adolescents. Analysis using multiple logistic regression with predictive factor model. Results: The highest aOR value is marital status 17.25 (95\% Cl 6.60-45.04). Education only finished elementary school aOR 4.94 (95\% Cl 1.08-22.45). Never accessed the internet aOR 3.37 (95\% Cl $0.85-13.37)$. For every 1 year increase in adolescent age, the odds increased by $3.32(95 \% \mathrm{Cl} 1.71-6.46)$ or 19 years old had the highest odds. Didn't work aOR 3.00 (95\% Cl 0.71-12.66). Living in rural areas aOR $2.55(95 \% \mathrm{Cl} 0.53-$ 12.13). Low knowledge of family planning methods has an AOR of 0.26 (0.051.22). Conclusion: The determinants of adolescent fertility in NTT Province are age, education, occupation, marital status, place of residence, internet use and knowledge of family planning methods. 


\section{PENDAHULUAN}

Secara global, jumlah penduduk usia muda 15-24 tahun yaitu 1.2 millyar, atau $16 \%$ dari populasi global. Remaja di Asia Tenggara dan Asia Timur mencapai 307 juta (United Nations, Department of Economic and Social Affairs, 2019). Selanjutnya, pada remaja usia 15-19 tahun, sekitar 90\% tinggal di negara berpenghasilan rendah dan menengah, yang juga dengan beban tingkat fertilitas remaja yang tinggi (Margarate N. Munakampe, Michelo, \& Zulu, 2021). Fertilitas remaja usia 15-19 tahun yang tinggi tersebut $90 \%$ terjadi pada ikatan perkawinan dan status kuintil ekonomi terendah (Geneva, 2017).

Fertiliitas remaja adalah kehamilan pada usia $<19$ tahun, termasuk telah melahirkan anak hidup, aborsi, lahir mati dan keguguran (Sentell et al., 2019). Fertilitas usia remaja Tahun 2019 di Indonesia berdasarkan data world bank sebesar 46 kelahiran per 1000 wanita usia 15-19 tahun. Angka ini hampir sama saja dengan 22 tahun sebelumnya di Tahun 1997 yakni sebesar 48 kelahiran per 1000 wanita usia 15-19 tahun. Hal ini menunjukkan upaya untuk menekan angka fertilitas usia remaja masih stagnant (The World Bank, 2019).

Berbagai konsekuensi negatif yang dimulai dari terjadinya fertilitas remaja baik dampak kesehatan, sosial dan ekonomi. Diantaranya risiko kesakitan dan kematian ibu pada ibu remaja, perilaku aborsi yang tidak aman, bayi dengan berat badan lahir rendah dan angka kematian bayi (Margarate Nzala Munakampe, Zulu, \& Michelo, 2018). Selanjutnya wanita yang melahirkan selama masa remaja bernasib lebih buruk daripada wanita yang menunda menjadi ibu hanya beberapa tahun diantaranya kualitas pekerjaan wanita, kualitas pekerjaan pasangan, ketidakstabilan pasar pernikahan, viktimisasi kekerasan dalam rumah tangga yang parah, dan bagian dari anak-anak yang meninggal (Margarate N. Munakampe et al., 2021).

Berdasarkan data Survei Demografi dan Kesehatan Indonesia, Provinsi Nusa Tenggara Timur merupakan provinsi dengan angka TFR (total fertility rate) tertinggi se Indonesia yaitu 3.37 anak per perempuan (Badan Kependudukan dan Keluarga Berencana Nasional et al., 2018). Angka ini masih jauh diatas rata-rata nasional yakni TFR Indonesia 2,42 anak per perempuan. Sedangkan tingkat fertilitas dalam perkawinan (TMFR/total marital fertility rate) Provinsi NTT adalah 5.00 anak per perempuan. Indeks perkawinan Provinsi Nusa Tenggara Timur adalah 0,67 (Badan Kependudukan dan Keluarga Berencana Nasional et al., 2018). Hal ini berarti bahwa perempuan di NTT menghabiskan $67 \%$ dari masa reproduksi mereka dalam status kawin yang membuat mereka terpapar terhadap melahirkan anak. Angka-angka ini tentunya tidak lepas dari kontribusi fertilitas pada usia remaja, yang juga akan mempengaruhi lama masa reproduksi.

Beberapa penelitian sebelumnya mempelajari faktor yang berhubungan dengan fertilitas remaja. Hasil penelitian menunjukkan bahwa ada hubungan yang positif antara fertilitas dengan peningkatan usia remaja 15-9 tahun (Raharja, 2014). Mereka yang bekerja umumnya mempunyai tingkat fertilitas lebih rendah dari yang tidak bekerja (Rahman \& Syakur, 2018). Remaja yang mengalami fertilitas di usianya mempunyai ratarata lama pendidikan lebih rendah daripada remaja yang fertilitas pada usia 20 tahun ke atas. Hal ini karena mereka cenderung tidak meneruskan pendidikannya karena telah menjadi ibu dan waktunya dihabiskan untuk merawat anaknya daripada belajar (Purbowati, 2019). Indikator lainnya menunjukkan bahwa faktor yang paling berpengaruh 
terhadap kejadian fertilitas, adalah keterpaparan media massa (Indisirasi, 2017). Selain itu tingkat pengetahuan ibu yang semakin baik digunakan mengambil keputusan yang tepat dan efektif tentang alat kontrasepsi yang digunakan dan keputusan melahirkan anak (Sari, 2017).

Penelitian ini mempelajari fertilitas remaja di Nusa Tenggara Timur yang pertama dengan memanfaatkan data SDKI Tahun 2017. Banyaknya masalah kependudukan dan kesehatan yang akan timbul apabila angka fertilitas remaja meningkat menjadi dasar rumusan masalah. Penelitian ini bertujuan mempelajari determinan fertilitas remaja di Provinsi di Nusa Tenggara Timur.

\section{METODE PENELITIAN}

Penelitian ini menggunakan data sekunder pada SDKI Tahun 2017 yang dilakukan oleh Badan Kependudukan dan Keluarga Berencana Nasional (BKKBN), Badan Pusat Statistik (BPS), dan Kementerian Kesehatan Republik Indonesia. Survei ini menggunakan desain cross sectional. Sampel pada penelitian ini adalah remaja usia 1519 tahun yang tercatat sebagai sampel terpilih di Provinsi Nusa Tenggara Timur sebanyak 401 remaja.

Variabel dependent fertilitas remaja adalah fertilitas yang dialami wanita usia 15-19 tahun, baik yang sudah pernah melahirkan ataupun sedang hamil anak pertama (kode variabel pada data set v220) dikategorikan $1=$ fertilitas $0=$ tidak fertilitas. Variabel independen ada 14 variabel. Usia (v012) dalam bentuk numerik, pendidikan (v016) yang dikategorikan $1=$ tamat SD $0=$ tamat SMP ke atas, pekerjaan (v717) yang dikategorikan $1=$ tidak bekerja $0=$ bekerja, status marital (v501) yang dikategorikan $1=$ pernah menikah atau pernah hidup bersama $0=$ tidak pernah, tempat tinggal (v025) yang dikategorikan $1=$ pedesaan $0=$ perkotaan, indeks kekayaan (v190) yang dikategorikan $2=$ bawah jika menengah bawah-terbawah $1=$ menengah $0=$ atas jika menengah atas-teratas, akses media (v157-v159) yang dikategorikan $1=$ akses kurang jika skor akses $\leq 30=j i k a$ akses cukup jika skor akses $>3$, penggunaan internet (v171a) yang dikategorikan $1=$ tidak pernah $0=$ pernah, jaminan kesehatan (v481) yang dikategorikan $1=$ tidak memiliki $0=$ memiliki, pengetahuan metode $\mathrm{KB}$ (v301) $1=$ tidak tahu jika tahu $\leq 8$ metode $\mathrm{KB} 0=$ tahu jika tahu $>8$ metode KB , pengetahuan masa subur (v217) yang dikategorikan $1=$ tidak tahu $0=$ tahu jika menjawab pertengahan siklus, pesan KB (v384a-c) 1=tidak jika tidak dengar pesan KB dari media TV, majalah/koran, dan radio $0=y a$ jika dengar pesan KB salah satu media, jumlah anak ideal (v614) $1=$ jika $>20=$ jika $\leq 2$, dan pernah melakukan hubungan seks (v531) 1=pernah jika menyebut usia pertama sex $0=$ tidak pernah.

Variabel yang secara teoritis berhubungan dengan fertilitas yang tidak dimasukkan adalah penggunaan KB sebelum memiliki anak dan unmeet need karena pada analisis pendahuluan diperoleh data bahwa tidak ada penggunaan KB pada kalangan remaja yang belum memiliki anak baik yang berstatus pernah kawin ataupun tidak pernah kawin. Variabel penggunaan KB tidak dimasukkan sehingga variabel unmeet need KB juga tidak dimasukkan. Variabel pernah melakukan hubungan seks yang diambil dari pertanyaan usia pertama melakukan hubungan seks juga tidak dimasukkan karena data analisis menunjukkan $100 \%$ mereka yang fertilitas pernah melakukan hubungan seks, sehingga variabel ini menjadi variabel antara dan berpotensi bias jika tetap dimasukkan.

Analisis menggunakan software stata. Analisis dilakukan tanpa pembobotan, didahului dengan analisis univariat untuk mendeskripsikan variabel, lalu analisis bivariat 
untuk skrining variabel secara substansi dan statistik, dan terakhir analisis multivariat untuk menentukan determinan fertilitas remaja dan mengontrol variabel confounder. Analisis multivariat yang digunakan adalah regresi logistik berganda dengan model faktor prediktif.

Penelitian ini menggunakan data yang diunduh setelah mendaftar pada situs DHS (https://dhsprogram.com). Prosedur dan kuesioner yang digunakan dalam survei DHS 2017 telah ditinjau dan disetujui oleh The Institutional Review Board (IRB) of ICF International dengan nomor FWA00000845.

\section{HASIL PENELITIAN}

Sampel pada penelitian ini sebanyak 401 remaja. Karakteristik fertilitas menunjukkan bahwa diantara remaja yang dikategorikan fertilitas yakni 22 dari 28 remaja telah memiliki anak satu, dan 7 dari 28 remaja sedang hamil, serta 1 remaja sedang hamil dan sudah memiliki anak satu.

Tabel 1. Distribusi Fertilitas Remaja di Provinsi Nusa Tenggara Timur Tahun 2017

\begin{tabular}{lrr}
\hline \multicolumn{1}{c}{ Variabel } & \multicolumn{2}{c}{ Jumlah } \\
\cline { 2 - 3 } & $\mathbf{n = 4 0 1}$ & $\%$ \\
\hline Jumlah anak & 379 & 94.51 \\
0 & 22 & 5.49 \\
1 & & \\
Saat ini hamil & 7 & 1.75 \\
$\quad$ Ya & 394 & 98.25 \\
$\quad$ Tidak & & \\
Fertilitas & 28 & 6.98 \\
$\quad$ Ya & 373 & 93.02 \\
$\quad$ Tidak & & \\
\hline
\end{tabular}

Sumber: data SDKI 2017

Distribusi variabel fertilitas diuraikan pada tabel 1, menilai fertilitas menggunakan 2 parameter yakni sedang hamil dan atau sudah memiliki anak. 5.49\% remaja telah memiliki anak satu orang dan $1.75 \%$ remaja saat survey sedang dalam keadaan hamil. Sehingga dikategorikan fertilitas sebesar $6.98 \%$ atau $28 / 401$ remaja.

Tabel 2. Distribusi Determinan Fertilitas Remaja di Provinsi Nusa Tenggara Timur Tahun 2017

\begin{tabular}{lcc}
\hline \multicolumn{1}{c}{ Variabel } & \multicolumn{2}{c}{ Jumlah } \\
\cline { 2 - 3 } & $\mathbf{n = 4 0 1}$ & $\%=\mathbf{1 0 0}$ \\
\hline Usia (15-19 tahun) & $16.96+-1.38$ SD \\
Pendidikan & & \\
$\quad$ Tamat SD & 38 & 9.48 \\
$\quad$ Tamat SMP + & 363 & 90.52 \\
Pekerjaan & & \\
$\quad$ Tidak bekerja & 332 & 82.79 \\
$\quad$ Bekerja & 69 & 17.21 \\
Status Marital & & \\
$\quad$ Pernah menikah & 13 & 3.24 \\
$\quad$ Pernah tinggal bersama & 13 & 3.24 \\
$\quad$ Tidak pernah & 375 & 93.52 \\
\hline
\end{tabular}




\begin{tabular}{|c|c|c|}
\hline \multirow{2}{*}{ Variabel } & \multicolumn{2}{|c|}{ Jumlah } \\
\hline & $n=401$ & $\%=100$ \\
\hline \multicolumn{3}{|l|}{ Tempat tinggal } \\
\hline Pedesaan & 265 & 66.08 \\
\hline Perkotaan & 136 & 33.92 \\
\hline \multicolumn{3}{|l|}{ Indeks Kekayaan } \\
\hline Menengah bawah-Terbawah & 330 & 82.29 \\
\hline Menengah & 22 & 6.23 \\
\hline Menengah atas-Teratas & 46 & 11.47 \\
\hline \multicolumn{3}{|l|}{ Akses Media } \\
\hline Kurang akses & 266 & 66.33 \\
\hline Cukup akses & 136 & 33.67 \\
\hline \multicolumn{3}{|l|}{ Penggunaan Internet } \\
\hline Tidak pernah & 175 & 43.64 \\
\hline Pernah & 226 & 56.36 \\
\hline \multicolumn{3}{|l|}{ Jaminan Kesehatan } \\
\hline Tidak memiliki & 163 & 40.65 \\
\hline Memiliki & 238 & 59.35 \\
\hline \multicolumn{3}{|l|}{ Pengetahuan Metode KB } \\
\hline Rendah & 369 & 92.71 \\
\hline Tinggi & 29 & 7.29 \\
\hline \multicolumn{3}{|l|}{ Pengetahuan Masa Subur } \\
\hline Tidak Tahu & 355 & 88.53 \\
\hline Tahu & 46 & 11.47 \\
\hline \multicolumn{3}{|l|}{ Mendengar Pesan KB } \\
\hline Tidak & 243 & 60.60 \\
\hline $\mathrm{Ya}$ & 158 & 39.40 \\
\hline \multicolumn{3}{|l|}{ Jumlah anak ideal } \\
\hline$>2$ & 147 & 36.66 \\
\hline$\leq 2$ & 254 & 63.34 \\
\hline \multicolumn{3}{|l|}{ Pernah hubungan seksual } \\
\hline $\mathrm{Ya}$ & 42 & 6.98 \\
\hline Tidak & 359 & 93.02 \\
\hline
\end{tabular}

Sumber: data SDKI 2017

Rata-rata usia sampel survei remaja adalah 17 tahun, dengan dominasi $90.52 \%$ mencapai pendidikan telah tamat SMP ke atas, dan berstatus tidak atau belum bekerja 82.79\%. Sampel penelitian ini juga melaporkan remaja lebih banyak yang tinggal di desa $66.08 \%$ dibandingkan perkotaan $33.92 \%$, dengan hidup pada keluarga dengan indeks kekayaan kategori menengah bawah-terbawah sebesar 82.29\%. (Tabel 2)

Keterjangkauan mereka pada media baik televisi, majalah/Koran, dan radio menunjukkan mereka yang memiliki akses kurang sebesar $66.33 \%$. Penggunaan internet di kalangan remaja juga masih rendah hanya 56.36 yang pernah menggunakan. Jaminan kesehatan pada remaja juga masih rendah hanya 59.35. (Tabel 2)

Pengetahuan metode KB dan masa subur juga sangat menjadi perhatian, mereka yang memiliki pengetahuan tinggi tentang metode KB hanya $7.29 \%$ dan masa subur $22.47 \%$. Diatas setengah dari mereka juga tidak pernah mendengar pesan KB baik melalui TV, koran/majalah maupun radio $60.60 \%$, namun $63.34 \%$ mereka mengatakan jumlah anak ideal $\leq 2$ anak. (Tabel 2 ) 
Remaja juga menjawab usia pertama mereka melakukan hubungan seks yang kemudian dikategorikan menjadi variabel pernah melakukan hubungan seks. Sebanyak $6.98 \%$ atau 42 remaja pernah melakukan seks. Sehingga 28 dari 42 remaja yang pernah melakukan seks mengalami fertilitas.

Tabel 3. Analisis Bivariat Determinan dan Fertilitas Remaja di Provinsi Nusa Tenggara Timur Tahun 2017

\begin{tabular}{|c|c|c|c|c|c|c|}
\hline \multirow[b]{2}{*}{ Variabel } & \multicolumn{4}{|c|}{ Fertilitas } & \multirow[b]{2}{*}{$\begin{array}{l}\text { OR Crude } \\
\text { (95\% Cl) }\end{array}$} & \multirow[b]{2}{*}{$\begin{array}{c}\text { P. } \\
\text { value }\end{array}$} \\
\hline & $\begin{array}{c}Y a \\
n=28\end{array}$ & $\%$ & $\begin{array}{c}\text { Tidak } \\
\mathrm{n}=373\end{array}$ & $\%$ & & \\
\hline Usia & \multicolumn{2}{|c|}{$18.25+-0.84 S D$} & \multicolumn{2}{|c|}{$16.87+-1.37 S D$} & & 0.000 \\
\hline \multicolumn{7}{|l|}{ Pendidikan } \\
\hline Tamat SD & 8 & 21.05 & 30 & 78.95 & $4.57(1.59-11.94)$ & \multirow[t]{2}{*}{0.000} \\
\hline Tamat SMP + & 20 & 5.51 & 343 & 94.49 & 1 & \\
\hline \multicolumn{7}{|l|}{ Pekerjaan } \\
\hline Tidak bekerja & 19 & 5.72 & 313 & 94.28 & $0.40(0.16-1.06)$ & \multirow[t]{2}{*}{0.030} \\
\hline Bekerja & 9 & 13.04 & 60 & 86.96 & 1 & \\
\hline \multicolumn{7}{|l|}{ Status Marital } \\
\hline Menikah & 9 & 32.14 & 4 & 1.07 & $103(26-406.90)$ & \multirow{3}{*}{0.000} \\
\hline Tinggal bersama & 11 & 39.29 & 2 & 0.54 & $252(47-1328.99)$ & \\
\hline Tidak Menikah & 8 & 28.57 & 367 & 98.39 & 1 & \\
\hline \multicolumn{7}{|l|}{ Tempat tinggal } \\
\hline Pedesaan & 25 & 9.43 & 240 & 90.57 & $4.61(1.36-24.26)$ & \multirow[t]{3}{*}{0.007} \\
\hline Perkotaan & 3 & 2.21 & 133 & 97.79 & 1 & \\
\hline \multicolumn{6}{|l|}{ Indeks Kekayaan } & \\
\hline Menengah-Terbawah & 27 & 8.18 & 303 & 91.82 & $4.00(1.35-30.23)$ & \multirow{3}{*}{0.120} \\
\hline Menengah & 0 & 0,00 & 25 & 100,00 & 1 & \\
\hline Menengah-Teratas & 1 & 2.17 & 45 & 97.83 & 1 & \\
\hline \multicolumn{7}{|l|}{ Akses Media } \\
\hline Kurang akses & 23 & 8.65 & 243 & 91.35 & $2.46(0.88-8.46)$ & \multirow[t]{2}{*}{0.066} \\
\hline Cukup akses & 5 & 3.70 & 130 & 96.30 & 1 & \\
\hline \multicolumn{7}{|l|}{ Penggunaan Internet } \\
\hline Tidak pernah & 17 & 9.71 & 158 & 90.29 & $2.10(0.89-5.10)$ & \multirow[t]{2}{*}{0.059} \\
\hline Pernah & 11 & 4.87 & 215 & 95.13 & 1 & \\
\hline \multicolumn{7}{|l|}{ Jaminan Kesehatan } \\
\hline Tidak memiliki & 14 & 8.59 & 149 & 91.41 & $1.50(0.64-3.50)$ & \multirow[t]{3}{*}{0.269} \\
\hline Memiliki & 14 & 5.88 & 224 & 94.12 & 1 & \\
\hline \multicolumn{6}{|l|}{ Pengetahuan Metode } & \\
\hline KB & 23 & 6.23 & 346 & 93.77 & $0.41(0.12-1.78)$ & \multirow[t]{2}{*}{0.119} \\
\hline $\begin{array}{l}\text { Rendah } \\
\text { Tinggi }\end{array}$ & 4 & 13.79 & 25 & 86.21 & 1 & \\
\hline \multicolumn{7}{|l|}{$\begin{array}{l}\text { Pengetahuan } \quad \text { Masa } \\
\text { Subur }\end{array}$} \\
\hline Tidak Tahu & 24 & 6.76 & 331 & 93.24 & $0.76(0.24-3.16)$ & \multirow[t]{2}{*}{0.628} \\
\hline Tahu & 4 & 8.70 & 42 & 91.30 & 1 & \\
\hline \multicolumn{7}{|l|}{ Mendengar Pesan KB } \\
\hline Tidak & 19 & 7.82 & 224 & 92.18 & $1.40(0.58-3.62)$ & 0.415 \\
\hline $\mathrm{Ya}$ & 9 & 5.70 & 149 & 94.30 & 1 & \\
\hline
\end{tabular}




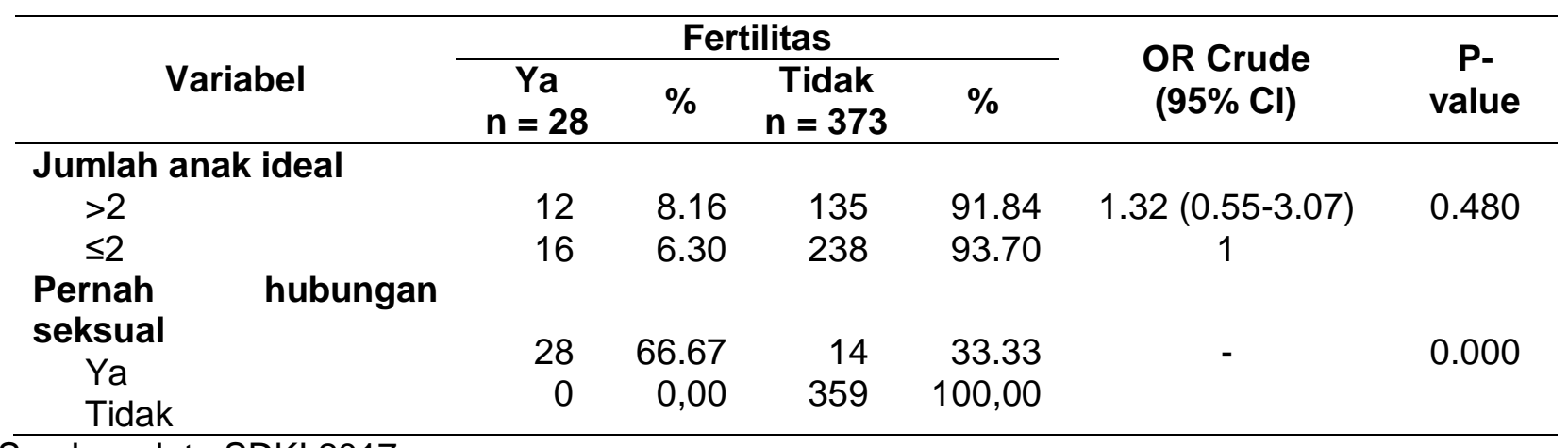

Sumber: data SDKI 2017

Kami mempelajari determinan fertilitas remaja di Provinsi Nusa Tenggara Timur mempertimbangkan 14 variabel prediktor. Diawali dengan menguji variabel dengan analisis beda proporsi dan beda mean (hanya variabel usia) yang menjadi dasar skrining atau seleksi variabel yang akan lanjut pada model multivariate.Terdapat 10 variabel yang dipertimbangkan secara substansi dan statistik yakni usia, pendidikan, pekerjaan, status marital, tempat tinggal, indeks kekayaan, akses media, penggunaan internet, jaminan kesehatan, pengetahuan metode KB (Tabel 3). Terdapat 4 variabel yang tidak diikutkan dalam analisis selanjutnya yakni pengetahuan masa subur, pesan KB, jumlah anak ideal, dan pernah melakukan hubungan seks (Tabel 3). Pernah melakukan hubungan seks tidak dimasukkan dalam model karena pada analisis menunjukkan $100 \%$ persen yang mengalami fertilitas juga adalah mereka yang pernah melakukan hubungan seksual sehingga variabel ini dipastikan menjadi variabel antara, sehingga jika dimasukkan dalam analisis lanjut hasil akan bias.

Tabel 4. Determinan Fertilitas Wanita Usia Muda di Provinsi Nusa Tenggara Timur Tahun 2017

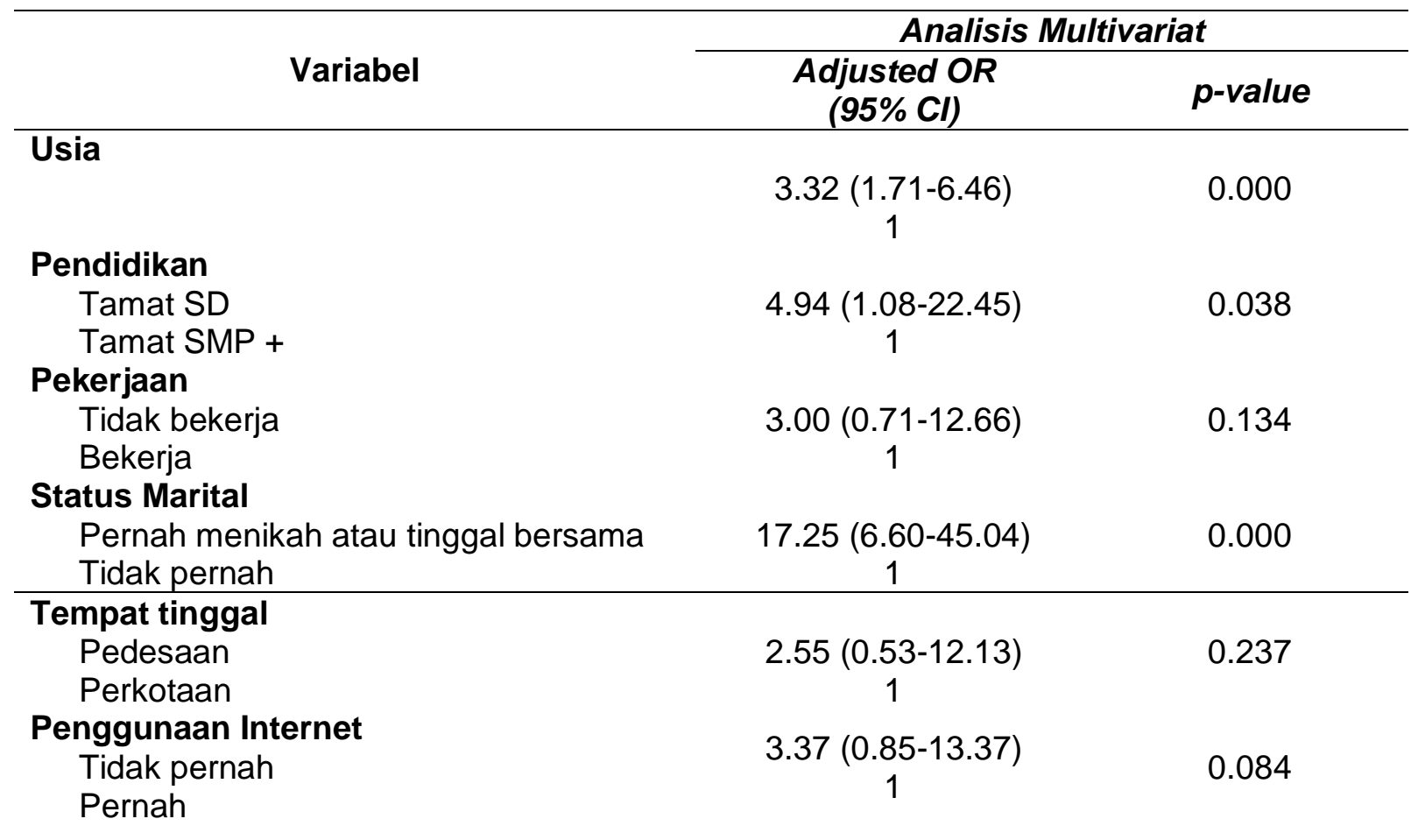




\begin{tabular}{lcc}
\hline Variabel & \multicolumn{2}{c}{ Analisis Multivariat } \\
\cline { 2 - 3 } & $\begin{array}{c}\text { Adjusted OR } \\
(\mathbf{9 5 \%} \mathbf{C l})\end{array}$ & $\boldsymbol{p}$-value \\
\hline $\begin{array}{l}\text { Pengetahuan Metode KB } \\
\text { Rendah } \\
\text { Tinggi }\end{array}$ & $0.26(0.05-1.22)$ & 0.089 \\
1
\end{tabular}

Sumber: data SDKI 2017

Berdasarkan pertimbangan substansi dan statistik pada model akhir menunjukkan terdapat 7 variabel yang disimpulkan menjadi determinan fertilitas remaja yakni usia, pendidikan, pekerjaan, status marital, tempat tinggal, penggunaan internet dan pengetahuan metode KB. Nilai asosiasi aOR terbesar menunjukkan besar risiko terbesar terhadap kejadian fertilitas setelah variabel confounder dikendalikan. Sehingga interpretasi ini diurutkan berdasarkan nilai aOR terbesar yakni status marital pernah menikah atau pernah tinggal bersama memiliki odds $17.25(95 \% \mathrm{Cl} 6.60-45.04)$ kali lebih besar mengalami fertilitas dibandingkan mereka yang tidak pernah menikah atau tinggal bersama. Remaja dengan pendidikan hanya tamat SD memiliki odds $4.94(95 \% \mathrm{Cl} 1.08-$ 22.45) kali lebih besar mengalami fertilitas dibandingkan remaja yang menamatkan pendidikan SMP ke atas. Remaja yang tidak pernah mengakses internet memiliki odds $3.37(95 \% \mathrm{Cl} 0.85-13.37)$ kali lebih besar mengalami fertilitas dibandingkan remaja yang tidak pernah menggunakan internet. Remaja rentang usia 15-19 tahun semakin meningkat usia semakin meningkatkan odds mengalami fertilitas, setiap peningkatan 1 tahun terjadi peningkatan odds sebesar $3.32(95 \% \mathrm{Cl} 1.71-6.46)$ kali atau usia 19 tahun memiliki odds paling tinggi. Remaja yang tidak bekerja memiliki odds $3.00(95 \% \mathrm{Cl} 0.71$ 12.66) kali lebih besar mengalami fertilitas dibandingkan remaja yang bekerja. Remaja yang tinggal di daerah perdesaan memiliki odds $2.55(95 \% \mathrm{Cl} 0.53-12.13)$ kali mengalami fertilitas dibandingkan remaja yang tinggal di kota (Tabel 4)

Selanjutnya variabel yang menunjukkan asosiasi proteksi yakni pengetahuan metode KB. Pengetahuan metode KB yang rendah memiliki odd $0.26(0.05-1.22)$ atau mencegah fertilitas dibandingkan remaja yang memiliki pengetahuan yang tinggi atau remaja pengetahuan $\mathrm{KB}$ rendah memiliki odds $1 / 0.26=3.84$ kali tidak fertil. (Tabel 4 )

\section{PEMBAHASAN}

Penelitian ini merepresentasikan populasi remaja di Provinsi Nusa Tenggara Timur dengan penelitian survei yang melibatkan pengambilan sampel dalam jumlah yang besar. Hal ini dilakukan untuk mencapai generalisasi atau kesimpulan dengan menerapkan metode sampling agar dapat mewakili populasi. Keterbatasan penelitian ini adalah hasil analisis tidak mempertimbangkan desain survei yaitu compex sampels, sehingga ada kemungkinan bias akibat perekrutan sampel yang berstrata. Beberapa variabel spesifik pada lokal wisdom tidak tersedia yang mungkin terkait dengan fertilitas di daerah NTT.

Penelitian ini menyimpulkan 7 variabel yang menjadi determinan fertilitas remaja yakni remaja yang berstatus pernah menikah atau pernah hidup bersama, usia yang lebih tua, pendidikan yang hanya tamat sekolah dasar, remaja yang tidak bekerja, remaja yang tinggal di pedesaan, dan tidak pernah menggunakan internet dan yang mengetahui banyak metode KB. Kondisi fertilitas remaja di Provinsi NTT mampu dijelaskan oleh faktor-faktor tersebut. Namun beberapa faktor yang tidak menjadi variabel dalam 
penelitian ini, seperti beberapa faktor kontekstual seperti norma perkawinan tradisional dan nilai-nilai agama juga memainkan peran dalam pengendalian fertilitas remaja (Haaland et al., 2019). Penduduk NTT yang mayoritas (89\%) beragama kristen. Agama tertentu biasanya menentang pandangan kesehatan global tentang membatasi fertilitas yang berbasis hak, tanpa memperhatikan pengguna seperti studi di Zambia (Haaland et al., 2019).

Status marital sebagai determinan fertilitas remaja. Status marital atau dalam konteks remaja dikenal dengan istilah pernikahan dini. Pernikahan dini tetap menjadi faktor kuat yang mendasari fertilitas remaja. Keyakinan bahwa nilai dan peran utama seorang anak perempuan dalam masyarakat adalah sebagai istri dan/atau ibu dapat sangat berdampak terhadap keinginan dan keputusan dalam keluarga berencana. Pernikahan dini seringkali memperburuk tekanan ini. Pernikahan dini dapat memberikan pengakuan dan persetujuan sosial untuk hubungan seksual, itu juga menempatkan tekanan pada anak perempuan untuk membuktikan kesuburan dan melahirkan anak. Status pernikahan merupakan faktor yang tidak bisa diabaikan. Saat ini, sepertiga anak perempuan di negara berkembang menikah sebelum usia 18, dan satu dari sembilan menikah pada usia 15 , Sementara keduanya menikah dan gadis yang belum menikah aktif secara seksual, sekitar 90 persen kelahiran dialami oleh ibu remaja terjadi dalam pernikahan (Chitempa, 2017).

Perkawinan anak dikaitkan dengan rendahnya penggunaan kontrasepsi sebelum anak pertama, diikuti oleh kehamilan selanjutnya dengan jarak yang pendek. Meskipun ada undang-undang yang melarang pernikahan sebelum usia 18 tahun di Indonesia. Pernikahan dini lebih disukai oleh keluarga karena alasan yang berbeda biasanya di daerah pedesaan. Salahsatunya, keluarga lebih memilih untuk menikahkan anak perempuan mereka saat mereka masih hidup atau sebelum mereka tua.Penelitian ini juga membuktikan bahwa remaja yang tinggal di pedesaan memiliki peluang yang lebih besar 2.5 kali lipat dibandingkan di perkotaan. Penelitian lain menemukan menjadi penduduk pedesaan dan proporsi pengguna kontrasepsi yang lebih rendah di masyarakat secara signifikan meningkatkan kemungkinan mengalami kehamilan remaja (Birhanu, Kebede, Kahsay, \& Belachew, 2019).

Pendidikan sebagai determinan fertilitas pada remaja. Secara global tingkat pendidikan telah menjadi faktor dalam definisi status sosial ekonomi, dan sering dikatakan bahwa status sosial ekonomi yang rendah terkait dengan berkurangnya akses ke pendidikan dan layanan kesehatan yang berkualitas. Peningkatan sosial ekonomi lainnya; meliputi peningkatan pengembangan keterampilan, peningkatan kekuatan pengambilan keputusan, dan kontrol wanita yang lebih besar atas sumber daya rumah tangga juga menjadi kunci dalam memahami preferensi fertilitas di kalangan wanita (Atake \& Gnakou Ali, 2019). Pengembangan keterampilan memungkinkan remaja untuk mendapatkan pekerjaan yang layak, semakin tinggi target wanita terhadap pekerjaan semakin memungkinkan untuk menjadi alasan menunda fertilitas untuk mencapai karir tertingginya. Penelitian ini juga membuktikan bahwa remaja wanita yang tidak bekerja lebih memiliki peluang 3 kali lebih besar mengalami fertilitas. Dengan demikian, sederhanya bahwa tantangan fertilitas secara global dapat didefinisikan sebagai fungsi dari status sosial ekonomi, yang selanjutnya dapat dikaitkan dengan kelahiran anak usia dini atau remaja (Margarate Nzala Munakampe, Fwemba, Zulu, \& Michelo, 2021). 
Pendidikan merupakan faktor penting yang mendasari fertilitas remaja karena beberapa alasan. Pada usia 15 tahun sebagian besar anak remaja telah mencapai kematangan seksual, dan lingkungan sekolah dapat memberikan perlindungan yakni remaja wanita yang terdaftar di sekolah cenderung tidak memulai aktivitas seksual atau menikah pada usia dini (C. Lloyd, 2007). Remaja dengan masa sekolah lebih lama memungkinkan remaja untuk mendapatkan pengetahuan tentang anggota tubuh mereka dan tahu serta mampu untuk mencegah kehamilan. Masa sekolah yang lama biasanya juga dikaitkan dengan investasi besar untuk sumber daya manusia yang berkualitas karena menjadi modal memasuki pasar tenaga kerja dan mereka cenderung menikah lebih lambat serta keinginan memiliki anak lebih ditunda (Council \& Medicine, 2005).

Remaja yang tidak pernah menggunakan internet menjadi deterninan fertilitas pada penelitian ini. Penggunaan internet yang luas membuka peluang baru untuk mengakses pendidikan dan pengguna layanan kesehatan terkait remaja (World Health Organization, 2017). Akses media sosial yang terbatas menjadikan remaja tidak mendapatkan informasi yang memadai termasuk pentingnya menunda fertilitas pada usianya, akses informasi layanan remaja terkait kesehatan reproduksi serta berbagai dampak positif dari informasi dan teknologi yang berkualitas. Walaupun saat ini, penggunaan media sosial untuk menyebarkan informasi dengan melibatkan remaja telah diperkenalkan. Namun, tidak dapat dipungkiri ini belum merata sehinga kebutuhan untuk meningkatkan permintaan dan menjangkau mereka yang tidak dapat diakses platform. Oleh karena itu, pergeseran fokus layanan kesehatan dengan langsung menjangkau remaja di rumah dan komunitas mereka sangat perlu ditekankan untuk mempromosikan perilaku reproduksi sehat sehingga remaja tidak rentan terhadap fertilitas dini (Margarate N. Munakampe et al., 2021). Fakta lain terkait informasi kesehatan reproduksi pada remaja yang belum menikah terkadang dianggap sesuatu yang tabu. Pernikahan menjadi syarat sosial terhadap akses informasi dan layanan kontrol/menunda fertilitas. Pengambilan keputusan untuk memanfaatkan informasi dan layanan kesehatan reproduksi (Zimmerman, Li, Moreau, Wilopo, \& Blum, 2019), biasanya menempatkan mereka dalam kurung kelompok yang terpinggirkan atau terpencil secara sosial (Alakhunova, Diallo, Martin, Campo, \& Tallarico, 2015).

Pengetahuan metode KB yang baik meningkatkan peluang fertilitas pada remaja pada penelitian ini. Hal ini karena kemungkinan dikalangan mereka mengetahui banyak jenis/metode KB baik modern maupun tradisional namun tidak mendapatkan pendidikan seksual yang konkret dan informasi terkait tidak tersedia untuk remaja. Sebagian besar komunitas, kepercayaan budaya di dalam komunitas mencegah remaja mendapatkan lebih banyak informasi tentang seksualitas. Secara budaya, orang tua tidak bisa mendiskusikan masalah seksual dengan anak-anak mereka. Sampai mereka dihadapkan pada masalah kehamilan yang tidak diinginkan dan komplikasi terkait lainnya. Hambatan budaya mungkin juga mempengaruhi keputusan mereka tentang penggunaan kontrasepsi. Pemikiran mereka tentang kebutuhan termasuk kebutuhan kontrasepsi sebagian besar ditentukan oleh orang dewasa, dalam keluarga seperti ini perkawinan remaja sering mendorong fertilitas dini. Ketakutan akan efek samping penggunaan kontrasepsi dan pendidikan yang terbatas juga dapat mempengaruhi pilihan mereka untuk menunda masa kehamilan (Birhanu et al., 2019).

Remaja dalam penelitian ini yang mengalami fertilitas dominan telah berstatus menikah. Sebagian remaja telah memahami bahwa seks sebelum menikah dipandang 
sebagai dosa yang mereka dengarkan dari keluarga mereka, kerabat mereka yang lain, dari tempat ibadah dan di sekolah (United Nations, Department of Economic and Social Affairs, 2013). Namun beberapa remaja memandang akses ke kontrasepsi dan aborsi sebagai hak, sehingga mereka merasa perlu mengetahui tentang kontrasepsi dan aborsi agar mereka dapat membuat keputusan yang lebih baik (Margarate N Munakampe, Michelo, \& Zulu, 2021). Sebuah evaluasi program remaja telah menemukan bahwa kesehatan seksual dan reproduksi berbasis sekolah dengan pendidikan efektif untuk meningkatkan kesehatan seksual dan reproduksi remaja dalam hal perubahan pengetahuan dan perilaku (Akinrinola \& Shawn, 2010).

Oleh karena itu, akses terhadap kesehatan reproduksi dan sexual dengan memberikan otonomi pada remaja. Dengan melibatkan remaja dan orang-orang yang berpengaruh dalam pengendalian fertilitas remaja yakni orang tua, guru, petugas kesehatan, dan pembuat kebijakan. Peningkatan kemandirian finansial remaja yang menambah kekuatan pengambilan keputusan untuk memanfaatkan informasi dan layanan kesehatan reproduksi dan seksual (Zimmerman et al., 2019). Mendukung penerimaan secara budaya bagi remaja yang ingin berusaha mengendalikan fertilitas mereka, tanpa dipertanyakan orang tua dan meradikalisasi remaja tersebut. Seperti yang ditunjukkan oleh penelitian lain (Kennedy et al., 2013), upaya ini terjadi meskipun ada ketidaknyamanan mendiskusikan masalah kesehatan reproduksi dan seksual dengan orang tua yang lebih tua, terutama orang tua mereka sendiri.

\section{SIMPULAN DAN SARAN}

Determinan fertilitas remaja di Provinsi Nusa Tenggara Timur yakni usia, pendidikan, pekerjaan, status marital, tempat tinggal, penggunaan internet dan pengetahuan metode KB. Berdasarkan hasil penelitian ini disarankan upaya mengendalikan fertilitas remaja dilakukan dengan fokus sasaran pada remaja usia 15-19 tahun untuk mencapai pendidikan formal yang tinggi dilakukan dengan peningkatan partisipasi sekolah, upaya kesempatan bekerja pada remaja, menunda usia perkawinan dini, mendekatkan akses internet, remaja yang tinggal di pedesaan dimudahkan akses pendidikan dan lapangan kerja, informasi metode KB yang disertai pemahaman yang benar tentang kesehatan reproduksi.

\section{UCAPAN TERIMA KASIH}

Terima kasih kepada 1) Direktorat Riset dan Pengabdian Masyarakat (DRPM), Kementerian Pendidikan, Kebudayaan, Riset, dan Teknologi atas pendaan dalam pelaksanaan penelitian ini melalui skema penelitian dosen pemula (PDP) Tahun 2020 2) Kepada Demographic and Health Survey (DHS) Program sebagai penyedia data set SDKI Tahun 2017.

\section{DAFTAR PUSTAKA}

Akinrinola, B., \& Shawn, M. (2010). Removing barriers to adolescents' access to contraceptive information and services. Studies in Family Planning, 41(2), 117-124. https://doi.org/10.1111/J.1728-4465.2010.00232.X

Alakhunova, N., Diallo, O., Martin, I., Campo, D., \& Tallarico, W. (2015). Defining Marginalization: An Assessment Tool. In The George Washington University. Retrieved from https://elliott.gwu.edu/sites/g/files/zaxdzs2141/f/World Fair Trade Organization.pdf 
Atake, E.-H., \& Gnakou Ali, P. (2019). Women's empowerment and fertility preferences in high fertility countries in Sub-Saharan Africa. BMC Women's Health 2019 19:1, 19(1), 1-14. https://doi.org/10.1186/S12905-019-0747-9

Badan Kependudukan dan Keluarga Berencana Nasional, Badan Pusat Statistik, Kementerian Kesehatan, \& USAID. (2018). Survei Demografi dan Kesehatan Indonesia 2017. Jakarta: Badan Kependudukan dan Keluarga Berencana Nasional. Retrieved from https://www.bps.go.id/statictable/2020/10/21/2111/laporan-survei-demografi-dankesehatan-indonesia.html

Birhanu, B. E., Kebede, D. L., Kahsay, A. B., \& Belachew, A. B. (2019). Predictors of teenage pregnancy in Ethiopia: a multilevel analysis. BMC Public Health 2019 19:1, 19(1), 1-10. https://doi.org/10.1186/S12889-019-6845-7

Chitempa, N. (2017). Girl Empowerment and Child Marriage: Empowering girls to prevent and end child marriage in Zambia (Goteborgs Universitet). Goteborgs Universitet. Retrieved from https://gupea.ub.gu.se/handle/2077/57187

Council, N. R., \& Medicine, I. of. (2005). Growing Up Global: The Changing Transitions to Adulthood in Developing Countries (C. B. Lloyd, Ed.). Washington, DC: The National Academies Press. https://doi.org/10.17226/11174

Geneva, W. H. O. (2017). Global Accelerated Action for the Health of Adolescents (AA-HA!) Guidance to Support Country Implementation (Licence: C). Geneva. Retrieved from https://www.who.int/publications/i/item/9789241512343

Haaland, M. E. S., Haukanes, H., Zulu, J. M., Moland, K. M., Michelo, C., Munakampe, M. N., \& Blystad, A. (2019). Shaping the abortion policy - competing discourses on the Zambian termination of pregnancy act. International Journal for Equity in Health 2019 18:1, 18(1), 111. https://doi.org/10.1186/S12939-018-0908-8

Kennedy, E. C., Bulu, S., Harris, J., Humphreys, D., Malverus, J., \& Gray, N. J. (2013). "Be kind to young people so they feel at home": a qualitative study of adolescents' and service providers' perceptions of youth-friendly sexual and reproductive health services in Vanuatu. BMC Health Services Research 2013 13:1, 13(1), 1-12. https://doi.org/10.1186/1472-696313-455

Lloyd, C. (2007). The role of schools in promoting sexual and reproductive health among adolescents in developing countries. In Poverty, Gender, and Youth. https://doi.org/10.31899/pgy2.1048

Munakampe, Margarate N, Michelo, C., \& Zulu, J. M. (2021). A critical discourse analysis of adolescent fertility in Zambia: a postcolonial perspective. Reproductive Health, 18(1), 75. https://doi.org/10.1186/s12978-021-01093-z

Munakampe, Margarate Nzala, Fwemba, I., Zulu, J. M., \& Michelo, C. (2021). Association between socioeconomic status and fertility among adolescents aged 15 to 19: an analysis of the 2013/2014 Zambia Demographic Health Survey (ZDHS). Reproductive Health 2021 18:1, 18(1), 1-11. https://doi.org/10.1186/S12978-021-01230-8

Munakampe, Margarate Nzala, Zulu, J. M., \& Michelo, C. (2018). Contraception and abortion knowledge, attitudes and practices among adolescents from low and middle-income countries: a systematic review. BMC Health Services Research 2018 18:1, 18(1), 1-13. https://doi.org/10.1186/S12913-018-3722-5

Purbowati, A. (2019). Fertilitas Remaja di Indonesia: Hubungan antara Melahirkan pada Usia Remaja dan Capaian Pendidikan Wanita. Jurnal Kependudukan Indonesia, 14(2), 153-164. https://doi.org/10.14203/jki.v14i2.391

Raharja, M. B. (2014). Fertilitas Remaja di Indonesia. Kesmas: National Public Health Journal, 9(1), 6-13. https://doi.org/10.21109/kesmas.v9i1.449

Rahman, A., \& Syakur, R. M. (2018). Menelusur Determinan Tingkat Fertilitas. EcceS (Economics, Social, and Development Studies), 5(2), 57-77. 
https://doi.org/10.24252/ecc.v5i2.7079

Sari, N. (2017). Determinan Fertilitas Melalui Pendekatan Total Fertility Rate (TFR) di Indonesia: Analisis Data Survei Demografi Kesehatan Indonesia (SDKI) Tahun 2007. Jurnal Dunia Kesmas, $\quad 6(2), \quad$ 55-62. $\quad$ Retrieved from http://ejurnalmalahayati.ac.id/index.php/duniakesmas/article/view/480

Sentell, T., Câmara, S. M. A. da, Ylli, A., Velez, M. P., Domingues, M. R., Bassani, D. G., ... Pirkle, C. M. (2019). Data gaps in adolescent fertility surveillance in middle-income countries in Latin America and South Eastern Europe: Barriers to evidence-based health promotion. South Eastern European Journal of Public Health, 11, 11. Retrieved from https://www.ncbi.nlm.nih.gov/pmc/articles/PMC7236900/

The World Bank. (2019). Adolescent fertility rate (births per 1,000 women ages 15-19) - Indonesia / Data. Retrieved from https://data.worldbank.org/indicator/SP.ADO.TFRT?locations=ID

United Nations, Department of Economic and Social Affairs, P. D. (2013). Adolescent Fertility since the International Conference on Population and Development (ICPD) in Cairo. In United Nations publication. Retrieved from https://www.un.org/en/development/desa/population/publications/pdf/fertility/Report_Adoles cent-Fertility-since-ICPD.pdf

United Nations, Department of Economic and Social Affairs, P. D. (2019). World Population Prospects. Retrieved from https://population.un.org/wpp/

World Health Organization. (2017). Global Accelerated Action for the Health of Adolescents (AAHA!) Guidance to Support Country Implementation. Geneva, Switzerland: World Health Organization. Retrieved from https://www.who.int/publications/i/item/9789241512343

Zimmerman, L. A., Li, M., Moreau, C., Wilopo, S., \& Blum, R. (2019). Measuring agency as a dimension of empowerment among young adolescents globally; findings from the Global Early Adolescent Study. SSM - Population Health, 8, 100454. https://doi.org/10.1016/j.ssmph.2019.100454 